\title{
Corporate Governance Practices in Developing Countries: The Case for Kenya
}

\author{
Benjamin Mwanzia Mulili (Corresponding author) \\ Graduate College of Management \\ Southern Cross University \\ P.O Box 42, Tweed Heads NSW 2485, Australia \\ Tel.+61-415-951-932_ E-mail: bmwanzia@yahoo.com \\ Dr. Peter Wong \\ Graduate College of Management \\ Southern Cross University \\ P.O Box 42, Tweed Heads NSW 2485, Australia \\ Tel. +61-431-489 -908Ｅ-mail: wongpete@optusnet.com.au
}

Received: November 22, $2010 \quad$ Accepted: December 13, 2010 doi:10.5430/ijba.v2n1p14

\begin{abstract}
This paper examines the concept of corporate governance from a historical perspective. The paper explores how the agency theory and stewardship theory affect corporate governance practices. The focus of the paper is on public universities in Kenya. An extensive review of literature indicates that the ideals of good corporate governance have been adopted by developing countries since the 1980s. Developing countries differ from developed countries in a wide variety of ways. Therefore, there is need for developing countries to develop their own corporate governance models that consider the cultural, political and technological conditions found in each country. This paper explores the challenges encountered by developing countries in the process of adopting the corporate governance ideals. The authors have identified knowledge gaps in corporate governance that can form the basis for future research projects.
\end{abstract}

Keywords: Corporate governance, Developing countries, Public sector organizations, Public universities.

\section{Introduction}

Many contemporary organizations continuously seek for ways to improve on their activities. This explains why concepts such as business process improvement, re-engineering, total quality management, strategic management, corporate citizenship, corporate social responsibility (CSR) and business ethics have become buzzwords in the contemporary business world. This paper focuses on corporate governance which is an important aspect of private and public organizations.

\subsection{Definitions of corporate governance}

It is difficult to define the concept of corporate governance in a universally acceptable way because definitions vary from country to country. Moreover, countries differ from each other in terms of culture, legal systems and historical developments (Ramon, 2001). This explains why there is a wide range of definitions of the concept of corporate governance.

Shleifer and Vishny (1997) define corporate governance in terms of the ways in which suppliers of finance to a firm assure themselves of a good return to their investment. This definition is shallow in that it emphasises the suppliers of finance and it does not recognize the relationships between a firm's stakeholders and managers. Each firm has numerous stakeholders whose different interests must be taken care of. This is why corporate governance has also been referred to as a collective group of people united as one body with the power and authority to direct, control and rule an organization (Ruin, 2001).

The Australian Standard (2003) defines corporate governance as the process by which organizations are directed, controlled and held to account. This implies that corporate governance encompasses the authority, accountability, stewardship, leadership, direction and control exercised in the process of managing organizations. Since this definition recognizes the need for checks and balances in the process of managing organizations, it can be considered to be more comprehensive (Gregory, 2000). Moreover, it is similar to the definitions provided by the Audit Commission (2009) and CIPFA/SOLACE (Chartered Institute of Public Finance and Accountancy and the Society of Local Authority Chief Executives 2007) which emphasise the core aspects of accountability and control in the governance of organizations. 
According to Turnbull (1997) corporate governance influences all activities of firms that produce goods or provide services. Colley et al. (2004) opine that corporate governance is the act or process of governing while Cadbury (2000) defines corporate governance in terms of the systems by which firms are directed and controlled. The presence of different definitions indicates that each author formulates a definition that spins around his or her theme (Demb \& Neubauer, 1992). In fact, Wallace and Zinkin (2005) point out that the term good corporate governance is easy to phrase but difficult to understand and appreciate.

\subsection{Background of corporate governance}

McNutt (2010) argues that the concept of governance has been applied in both economics and law for centuries and it has been understood to mean enforcement of contracts, protection of property rights and collective action. In fact, governance is associated with people operating within organizations. Organizations allow for achieving outcomes beyond the reach of a single person (Scott, 2003). Nevertheless, organizations must be governed properly in order for them to achieve their objectives.

The concept of corporate governance began to be used and spoken about more commonly in the 1980s (Parker, 1996) but it originated in the Nineteenth Century when incorporation was being advocated for as a way of limiting liability (Fletcher, 1996; Vinten, 2001). Adams (2002) perceives creation of the registered company to be the real starting point for any discussion on corporate governance. The Joint Stock Companies Act 1844 (UK) supported the registration of companies. The rise of modern corporations led to a separation of control from ownership ((Berle \& Means, 1967). This separation meant that owners of firms no longer controlled the firms' actions because that was the role of professional managers (Kiel \& Nicholson, 2003). This gave rise to the need for corporate governance frameworks to protect owners of firms from the actions of professional managers. As a matter of fact, the Limited Liability Act 1855 (UK) was passed to protect shareholders from debt beyond their investment.

According to Francis (2000) the concept of corporate governance gained prominence in the 1980s because this period was characterised by stock market crashes in different parts of the world and failure of some corporations due to poor governance practices. Corporate collapse was the predominant driver for change to corporate governance codes (United Nations, 1999). As more corporate entities in different parts of the world collapsed in 1980s, there was a change of attitude with much higher performance expectations being placed on management boards of firms. There was also a growing realization that managers are to run firms while boards are to ensure that firms are run effectively and in the right direction (Adams, 2002). Directors and managers require different sets of skills and managers do not necessarily make good directors.

Prevention of corporate failure was not the only reason that led to adoption of the corporate governance ideals. On a positive note, there was a growing acknowledgement that improved corporate governance was crucial for the growth and development of the whole economy of a country (Clarke, 2004; Department of Treasury, 1997). Other studies established strong links between the performance of corporations and the governance practices of their boards (Gregg, 2001; Hilmer, 1998; Kiel \& Nicholson, 2002; OECD, 1998). Moreover, a study carried out in the United States by Gompers, Ishii and Metrick (2003) found a strong correlation between good corporate governance practices and superior shareholder performance. The study also revealed that two-thirds of investors were prepared to pay more for shares of companies that had good corporate governance practices. Nevertheless, Cutting and Kouzim (2000) did not find any significant relationship between the performance of firms and the governance practices of their boards.

\subsection{Evolution of the concept of corporate governance}

The idea of corporate governance was quickly adopted in different parts of the world but with some major variations because circumstances vary from country to country. Consequently, a variety of corporate governance frameworks were developed. Nevertheless, two main approaches of corporate governance can be identified, with distinctions arising from the different legal systems at work in different countries.

Countries that followed civil law (e.g. France, Germany, Italy and Netherlands) developed corporate governance frameworks that focused on stakeholders. In those countries, the role of corporate governance was to balance the interests of a variety of key groups such as employees, managers, creditors, suppliers, customers and the wider community (Solomon \& Solomon, 2004). This approach was known as the insider model of corporate control as it recognized that the greatest control in a firm was held by those who were closest to its actual workings(Department of Treasury, 1997). On the other hand, countries that had a tradition of common law (e.g. Australia, United Kingdom, USA, Canada and New Zealand) developed corporate governance structures that focussed on shareholders' returns or interests. In their case corporate governance was supposed to ensure that corporations achieved the objectives set by their owners. Moreover, shareholders could hold a firm's management responsible for attaining the firm's goals which include profits. This approach was known as the outsider model of corporate control as it recognized the distance between the management of a firm and its owners (Department of Treasury, 1997). 
Although the two approaches to corporate governance were different, they had a few similarities. For example, they held that the management boards of firms were to be elected by shareholders to set policies and then delegate to management the authority to manage the firms (Hilmer, 1998). In any case, most countries adopted corporate governance systems that were a mixture of the two extreme forms (Solomon \& Solomon, 2004).

The adoption of the corporate governance philosophy does not necessarily prevent corporate failures and scandals. Examples of failed corporations include Enron and WorldCom in the United States and the Golden Quadrilateral in India (Kakabadse \& Kakabadse, 2003). Consequently, there has been debate about what needs to be included in a comprehensive corporate governance framework. Some scholars argue that a comprehensive corporate governance framework should include greater use of independent directors, access to outside advice for boards, review of board and executive remuneration and limitations on the power of CEOs (Cutting \& Kouzim, 2002; Monks, 2002).

Corporate governance is now an international topic due to globalization of businesses. It is acknowledged to play a major role in the management of organizations in both developed and developing countries. Nevertheless, Davies and Schlitzer (2008) note that corporate governance practices are not uniform across nations. In fact, the Organisation for Economic Cooperation and Development (1998) acknowledges the lack of a single model of corporate governance practice that is applicable to all organizations even within one country. Consequently, every country adopts a unique set of corporate governance procedures that are based on factors such as the country's legal and financial system, corporate ownership structures, culture and economic circumstances.

\section{Theoretical framework for corporate governance}

Neuman (2006) defines a theory as a system of interconnected ideas that condense and organize knowledge about the world. The agency theory and the stewardship theory are the main theories underlying the concept of corporate governance.

\subsection{Agency theory}

It has been pointed out that separation of control from ownership implies that professional managers manage a firm on behalf of the firm's owners (Kiel \& Nicholson, 2003). Conflicts arise when a firm's owners perceive the professional managers not to be managing the firm in the best interests of the owners. According to Eisenhardt (1989), the agency theory is concerned with analyzing and resolving problems that occur in the relationship between principals (owners or shareholders) and their agents or top management. The theory rests on the assumption that the role of organizations is to maximize the wealth of their owners or shareholders (Blair, 1995).

The agency theory holds that most businesses operate under conditions of incomplete information and uncertainty. Such conditions expose businesses to two agency problems namely adverse selection and moral hazard. Adverse selection occurs when a principal cannot ascertain whether an agent accurately represents his or her ability to do the work for which he or she is paid to do. On the other hand, moral hazard is a condition under which a principal cannot be sure if an agent has put forth maximal effort (Eisenhardt, 1989).

According to the agency theory, superior information available to professional managers allows them to gain advantage over owners of firms. The reasoning is that a firm's top managers may be more interested in their personal welfare than in the welfare of the firm's shareholders (Berle \& Means, 1967). Donaldson and Davis (1991) argue that managers will not act to maximize returns to shareholders unless appropriate governance structures are implemented to safeguard the interests of shareholders. Therefore, the agency theory advocates that the purpose of corporate governance is to minimize the potential for managers to act in a manner contrary to the interests of shareholders.

Proponents of the agency theory opine that a firm's top management becomes more powerful when the firm's stock is widely held and the board of directors is composed of people who know little of the firm. The theory suggests that a firm's top management should have a significant ownership of the firm in order to secure a positive relationship between corporate governance and the amount of stock owned by the top management (Mallin, 2004). Wheelen and Hunger (2002) argue that problems arise in corporations because agents (top management) are not willing to bear responsibility for their decisions unless they own a substantial amount of stock in the corporation.

The agency theory also advocates for the setting up of rules and incentives to align the behaviour of managers to the desires of owners (Hawley \& Williams, 1996). However, it is almost impossible to write a set of rules for every scenario encountered by employees. Consequently, the Australian Stock Exchange Corporate Governance Council (2003) associates good corporate governance with people of integrity.

Carpenter and Westpal (2001) opine that the agency theory is mainly applied by boards of profit making organizations to align the interests of management with those of shareholders. Dobson (1991) argues that the demands of profit making organizations are different from those of stakeholders such as shareholders, local communities, employees and customers. The conflicting demands can be used to justify actions that some may criticise as immoral or unethical depending on the stakeholder group. 
In summary, the idea of agency theory can be attributed to Coase (1937) but the ideals of the theory have only been applied to directors and boards since the 1980's. According to this theory, people are self-interested rather than altruistic and cannot be trusted to act in the best interests of others. On the contrary, people seek to maximize their own utility. The agency theory presents the relationship between directors and shareholders as a contract (Adams, 2002). This implies that the actions of directors, acting as agents of shareholders, must be checked to ensure that they are in the best interests of the shareholders.

\subsection{Stewardship theory}

The stewardship theory, also known as the stakeholders' theory, adopts a different approach from the agency theory. It starts from the premise that organizations serve a broader social purpose than just maximizing the wealth of shareholders The stakeholders' theory holds that corporations are social entities that affect the welfare of many stakeholders where stakeholders are groups or individuals that interact with a firm and that affect or are affected by the achievement of the firm's objectives (Donaldson \& Preston, 1995; Freeman, 1984). Successful organizations are judged by their ability to add value for all their stakeholders. Some scholars consider the natural environment to be a key stakeholder (Starik \& Rands, 1995; Dunphy et al., 2003).

Stakeholders can be instrumental to corporate success and have moral and legal rights (Donaldson \& Preston, 1995; Ulrich, 2008). When stakeholders get what they want from a firm, they return to the firm for more (Freeman, 1984; Freaman \& McVea, 2001).Therefore, corporate leaders have to consider the claims of stakeholders when making decisions (Blair, 1995) and conduct business responsibly towards the stakeholders (Manville \& Ober, 2003; White, 2009). Participation of stakeholders in corporate decision-making can enhance efficiency (Turnbull, 1994) and reduce conflicts (Rothman \& Friedman, 2001).

According to Kaptein and Van Tulder (2003), corporations adopt reactive or proactive approaches when integrating stakeholders' concerns in decision making. A corporation adopts a reactive approach when it does not integrate stakeholders into its corporate decision making processes. This results into a misalignment of organizational goals and stakeholder demands (Mackenzie, 2007). Some authors attribute scandals such as those of Enron and WorldCom to the failure to consider stakeholder concerns in decision making (Currall \& Epstein, 2003; Turnbull, 2002; Watkins, 2003; Zandstra, 2002). Following these scandals, some governments set up new regulations to align the interests of stakeholders with corporate conduct. For example, the Sarbanes-Oxley Act (SOX) was passed as a result of the collapse of Enron and WorldCom. Adams (2002) argues that the stewardship theory remains the theoretical foundation for much regulation and legislation. A proactive approach is used by corporations that integrate stakeholders' concerns into their decision-making processes and that establish necessary governance structures (de Wit et al., 2006).

In summary, the stewardship theory suggests that a firm's board of directors and its CEO, acting as stewards, are more motivated to act in the best interests of the firm rather than for their own selfish interests. This is because, over time, senior executives tend to view a firm as an extension of themselves (Clarke, 2004; Wheelen \& Hunger, 2002). Therefore, the stewardship theory argues that, compared to shareholders, a firm's top management cares more about the firm's long term success (Mallin, 2004).

\section{Key elements of a good corporate governance environment}

Perceptions of the elements that constitute good corporate governance vary from country to country since the business environment is not uniform in all countries. Nevertheless, some insights of key elements of good corporate governance are provided by the Australian Stock Exchange Corporate Governance Council (2003), Cadbury Report (1992), Sarbanes-Oxley Act (2002) and The Business Roundtable (2002).

According to the ASX Corporate Governance Council (2003), good corporate governance can be achieved on the basis of ten essential principles as shown on Table 1.

The Cadbury Report is named after Sir Adrian Cadbury who chaired the United Kingdom's Committee on the Financial Aspects of Corporate Governance (1992). According to Vinten (2001), the work of Cadbury's committee was groundbreaking. The Cadbury Report built on the work of the Treadway Report from the USA but it went further to provide a benchmark for corporate governance in many countries (Monks \& Minow, 1996).

According to the Cadbury report, good corporate governance must encompass four key aspects namely:

i. Establishing a board of directors that has clear responsibilities and whose role of directing or governing is different from that of the firm's managers.

ii. Establishing checks and balances in governance structures with no one person having unfettered power.

iii. Having a well balanced board team composed of executive and non executive directors.

iv. Ensuring transparency of a board in directing and controlling an organisation.

Following the collapse of Enron and WorldCom, the US Congress passed the Sarbanes-Oxley Act (SOX) in the year 2002. The SOX Act makes some substantive corporate governance provisions such as: 
- The need for an independent audit committee (section 301).

- A firm's principal executive and financial officers signing a statement that they have sufficient internal controls in place to ensure that financial statements do not contain any material misstatements (section 302).

- Independence of external auditors (sections 201-209).

The SOX Act also requires listed companies to have a majority of independent directors. The reasoning is that the board, acting as a representative of shareholders, cannot be seen to be objective in the oversight of management if the majority of the directors are from management (Colley et al., 2004).

The Business Roundtable (2002), an association of chief executive officers of American corporations, summarises the principles of good corporate governance as follows:

- A board has a paramount duty of selecting and overseeing a competent CEO and other senior managers.

- A firm's management has a responsibility to act in an effective and ethical manner in the process of increasing shareholder value.

- There is need for accurate and timely financial reporting.

- A firm must deal with its employees in a fair and equitable manner.

- A firm should have a corporate governance committee which comprises independent directors and which addresses issues such as nomination of directors, provision of information to a board and evaluation of a board's effectiveness.

- Independent directors should have an opportunity to meet outside the presence of a CEO and other management directors.

- A firm has a responsibility to communicate effectively with its shareholders and other stakeholders.

Another set of five good corporate governance principles is offered by the Organisation for Economic Co-operation and Development (OECD, 1999). The five principles are:

- Protection of shareholders' rights;

- Equitable treatment of all shareholders, including effective redress;

- Recognition of the rights of stakeholders;

- Timely and accurate disclosure of all matters that are regarded by a firm as being material. These may include financial, performance, ownership and governance matters;

- Effective monitoring of management and accountability of a board.

Table 2 is a synthesis of the different perspectives of good corporate governance. According to Table 2, there are eight main factors that form a good corporate governance environment.

\section{An overview of corporate governance practices of public sector organizations in developing countries.}

Effective and efficient management of public sector organizations is an issue of concern in many countries. Melese et al. (2004) argue that public sector organizations are increasingly being held more accountable for their performance and are therefore expected to operate efficiently and effectively. This means that public sector organizations have to search for ways to improve on their activities. Notable approaches include the use of performance contracts. Similarly, activity based management practices can increase transparency and efficiency when conducting government activities thereby assisting public sector organizations to achieve their objectives (Baird, 2007; Melese et al., 2004).

Historically, some public sector enterprises were formed to create employment for large numbers of people. However, in recent years, public sector management has become increasingly results and customer-focused (Jarrar \& Schiuma, 2007). This can be partly attributed to a growing unwillingness among many communities and governments to accept the continuation of historic commitments simply because they are historic. Some countries have also noticed diminishing differences between the private and public sectors. For instance, private sector organizations are now expected to take more social responsibility measures while the public sector is witnessing the need to focus on customers and to justify their existence. The contemporary business environment pays great attention to target, measurement, accountability, productivity gains and the continued relevance and value of specific activities or programs. The proper management of public sector organizations is therefore an issue of concern in developed and developing countries.

It has been noted that the concept of governance has existed for centuries. However, many African economies began to pay particular attention to the ideals of good governance in the beginning of the 1980s. According to Qudrat-I Elahi (2009), the term good governance was first mentioned in a 1989 World Bank report on Sub-Saharan Africa but since the 
1990s many donor agencies have sought the pursuit of good governance. Currently, corporate governance is a buzzword in the business world.

Corporate governance systems have evolved in a number of developing African countries (Solomon \& Solomon, 2004). However, Rwegasira (2000) argues that the concept of corporate governance is not necessarily the best solution for developing economies. This is because a number of developing countries face numerous problems that include unstable political regimes, low per capita incomes and diseases. Such problems require more elaborate solutions than simply adopting corporate governance concepts. Moreover, there is a general lack of research in corporate governance practices in developing countries, especially countries in the African continent (Okeahalam, 2004; Shleifer \& Vishny, 1997). This lack of research can be attributed to the fact that, for a long time, the issue of corporate governance did not receive adequate attention in the developing world. Yakasai (2001) observes that historically the ability of managers to run organizations was never questioned. Consequently, there was little concern for corporate governance or information disclosure and transparency. That situation has changed and the concept of corporate governance is currently acknowledged to play an important role in the management of organizations in developing economies.

Tsamenyi, Enninful-Adu and Onumah (2007) argue that developing countries are often faced with a multitude of problems that include uncertain economies, weak legal controls, protection of investors and frequent government intervention. These problems make it even more necessary for developing countries to adopt effective corporate governance structures. The pressures of an increasingly globalized world economy, democratization, IMF/World Bank's economic reforms and the recent financial scandals in the West have forced a number of developing countries to adopt the corporate governance ideals (Ahunwan, 2002; Gugler, Mueller \& Burcin, 2003; Reed, 2002). It has also been suggested that improved corporate governance systems can serve as an incentive for attracting foreign investment (Ahunwan, 2002).) In fact, it is poor economic performance and high international debt levels in emerging markets that forced the World Bank, IMF, and the IFC to intervene in an effort to improve the corporate governance systems of these markets (Reed 2002).

A number of developing countries have embraced the corporate governance ideals. However, developing countries practice corporate governance models that are different from the models adopted by developed countries (Rabelo \& Vasconcelos, 2002). This is partly due to the unique economic and political systems found in developing countries. Mensah (2002) argues that developing countries are poorly equipped to implement the type of corporate governance found in the developed market economies because developing countries are characterised by state ownership of firms, interlocking relationships between governments and financial sectors, weak legal and judiciary systems and limited human resource capabilities.

Corporate governance structures in developing countries are weak. Consequently, several measures have been suggested on how to improve such structures. Notable suggestions include the use of equity instead of debt for growth, increasing overall investor confidence through increased transparency, strengthening of capital market structures and encouraging the use of competition to improve performance of domestic firms (Reed, 2002).

The concept of competitions as a way of encouraging improvements in productivity has been adopted in many parts of the world (Marwa \& Zairi, 2008). Competitions mainly involve rewarding firms that excel in stated areas and they can be administered at a national level. Firms that have adopted total quality management (TQM) ideals often use the Malcolm Baldrige framework as a quality control tool for their activities.

\subsection{Corporate governance of public universities in Kenya.}

According to Tadjudin (2003) higher education is one of the most effective instruments for economic, political, human resources and social development. Similarly, Ogom (2007) argues that higher education not only enables a state to maintain a competitive advantage but it also stimulates scientific research that results into modernisation and social transformation. In a number of developing countries in Africa, education per se is assumed to equalize opportunities among people of different social classes, distribute income more fairly and develop a more employable labour force (Carnoy, 1986). On this basis, Ogom (2007) proposes that governments should financially support their institutions of higher education. Altbach (1970) opines that universities are political forces and sources of social mobility while Van den Bor and James (1991) argue that governments should consider universities as symbolic assets in the process of nation building in the same way that national flags or airline carriers are considered symbolic assets.

On recognizing the connection between higher education, science, technology and sustainable human development, the United Nations Educational, Scientific, and Cultural Organization (UNESCO) made higher education one of its top priorities (Guedeghe, 1997). Nevertheless, Van den Bor and James (1991) caution that higher education, or education in general, is not a magic bullet for development but it is only one of the many actors in a country's development process. Proper governance of institutions of higher education is necessary because such institutions play a strategic role in any country.

\subsection{History of higher education in Kenya}

In order to grasp the current governance practices adopted in public universities in Kenya, it is necessary to have a broad understanding of the history of higher education in Kenya. Mwiria and Ngethe (2006) explain that the history of 
higher education in Kenya can be traced back to 1922 when Makerere University in Uganda was founded as a technical college for African students from the East African countries of Uganda, Kenya and Tanganyika. In the initial years, this college offered post-school certificate courses in fields such as teacher training and carpentry. Following publication of the Asquith Report in 1949, the Makerere University Act was passed and this enabled the institution to legally transform itself into the University of East Africa which admitted its first undergraduate students in 1950 to study for degrees offered by the University of London.

As the demand for university education increased, there was need for universities in each of the three east African countries of Kenya, Uganda and Tanzania. Consequently, the Royal Technical College of East Africa was established in Nairobi, Kenya, in 1956 to provide instruction in courses leading to the Higher National Certificate offered in Britain and to prepare students for university degrees in engineering and commercial courses which were not offered by Makerere University. In 1961, the Royal Technical College of East Africa was renamed the Royal College of Nairobi and was turned into a university college, offering Bachelor of Arts and Bachelor of Science degrees in engineering, again from the University of London. In 1963, the Royal College became the University College of Nairobi and joined Makerere and Dar es Salaam Colleges to form the Federal University of East Africa. The Federal University of East Africa was dissolved in 1970 due to nationalistic pressures from Kenya and Tanzania. As a result, the University College of Nairobi was renamed the University of Nairobi and became Kenya's first fully-fledged university (Mwiria \& Ngethe, 2006). The University of Nairobi remained the only university in the country until the mid 1980s.

Currently, there are seven public universities in Kenya with an enrolment of 100,649 students (Muchiri, 2010). These are the University of Nairobi, Kenyatta University, Egerton University, Moi University, Jomo Kenyatta University of Agriculture and Technology, Maseno University and Masinde Muliro University of Science and Technology.

Besides the seven public universities in Kenya, there is a growing number of private universities. The private universities in Kenya can be categorized under three headings as outlined in Table 3.

The Kenyan government, through a 2010 Minister for Higher Education, hinted that it was contemplating uplifting 13 university colleges into full university status by the end of 2011. These colleges include Bondo, Chuka, Kimathi, Mombasa Polytechnic, Kenya Polytechnic, Pwani, Multi-media, Kabianga, Laikipia, Narok, Meru, South Eastern, and Kisii. A new Open University is expected to start its operations in Kenya in the early periods of the year 2011 (Muchiri, 2010).

\subsection{Challenges facing public universities in Kenya.}

Public universities in Kenya are faced with a myriad of challenges that include a rapid expansion of university education, reduced government funding, gender inequality, low research capability, students living in poor conditions and the spread of HIV/AIDS (Mutula, 2002).

\subsubsection{Rapid expansion of university education}

The widespread demand for higher education in Kenya, as evidenced by the rapid growth in the number of institutions and enrolments, is a major challenge for Kenyan public universities (Mwiria \& Ngethe, 2006). Currently there are about 100,000 students enrolled in seven public universities and the number is expected to expand to 157,000 by 2015 (Muchiri, 2010). This trend is not unique to Kenya. Carnoy (1986) confirms that most countries of the world have experienced rapid increase in demand for education of the labour force.

According to Oketch (2004), the expansion of higher education in Kenya before the advent of the SAPs was unprecedented. Wesonga et al. (2006) explain that the widespread demand for higher education in Kenya has been triggered by four main reasons namely:

- Massive expansion of primary and secondary education over the last three decades.

- Population growth rates that remained just under 4 per cent per year for most of the 1980s and 1990s.

- Increasing sophistication of an economy that demands a skilled work force.

- The determination by some religious organizations to open tertiary institutions primarily for their followers leading to the opening up of church-sponsored universities in the country.

The rapid expansion of public university education in Kenya in the midst of limited financial resources has led to deterioration of public universities in areas such as the quality of teaching and research, library facilities, halls of residence and student and staff representation (Mutula, 2002; Oketch, 2004). According to Ogom (2007), Kenyan public universities have lost their former glory due to low motivation of students and staff and poor infrastructure. 


\subsubsection{Reduced government funding}

In an effort to improve governance practices in Kenya, the IMF and the World Bank introduced Structural Adjustment programmes (SAPs) in the 1990s. The SAPs required the Kenyan government to reduce the funding of higher education, redirect more funding to primary education (Ogom, 2007) and divert more public resources from education to productive sectors (Varghese, 2006). Moreover, the Kenyan Government was pressurized to suspend construction of residential and non-residential buildings in universities, reduce maintenance workforce, introduce cost-sharing tuition, stop paying students allowances, and suspend free student meals and accommodation (Oketch, 2004). The implementation of this decision put financial pressure on Kenyan public universities. Currently, the Kenyan government allocates an annual uniform figure of \$h120, 000 (AUD \$1,540) per student irrespective of the course the student is pursuing (Muchiri, 2010). Reduced government funding of public universities has led to knowledge gap or reduced intellectual capital since the country is not able to develop the human resources it requires (Birdsall, 1996).

Public universities in Kenya have tried to put in place measures to generate income to augment their meagre government allocation. These measures include:

- Introduction of parallel or part-time degree programmes

- Renting out facilities like hostels during holidays and conference halls for social functions

- Opening the University of Nairobi mortuary to public use at a fee

- Production of crops, milk and beef on university farms.

- Provision of short-term courses, contract research for industry, and consultancy services.

- Introduction of diploma and distance education programs.

- Encouragement of individuals and organizations to contribute towards higher education in Kenya.

Nevertheless, the process of generating income by public universities has had some side effects. Rosenberg and Raseroka (2000) found out that public universities involved in income generating activities to meet shortfall in budgets experienced problems of skills and employees of such universities needed more training in the areas of finance, budgeting, accounting, IT, project proposal writing, negotiation skills and human resource management.

\subsubsection{Gender inequality and low research capability}

Kenyan public universities are often accused of producing graduates that are poorly equipped for the world of work. This forces employers to re-train fresh graduates, an activity which is time-consuming and expensive. This problem is compounded by the fact that some public universities have not effectively adopted the use of IT. According to Mutula (2002), IT can be used to improve the effectiveness of teaching and learning, individually tailor instruction and provide specialised education to small groups of learners.

\subsubsection{Students living in poor conditions}

Over the last two decades, the number of students enrolled in Kenyan public universities has been more than can be supported by the available facilities. This has led to poor living conditions as evidenced by the sharing of accommodation and students having to prepare their meals in the halls of residence. Poor living conditions have led to anxiety, stress, bitterness and hatred of the university by students and some members of the public. Moreover, the poor living conditions and ineffective teaching, lack of tutorials, threats by lecturers and sex related scandals tend to combine to produce student unrests. Student unrests in Kenya have also been associated with resistance to SAPs, unemployment, employment freezes in the public sector and demands for democratic reforms (Amutabi, 2002).

\subsubsection{HIV/AIDS}

Although there are no accurate data on the actual numbers, HIV/AIDS has affected a number of public university students and staff members. Public universities in Kenya have responded to this challenge by setting up AIDS control units (ACUs) that develop programs for the management of HIV/AIDS and that help to raise community awareness. The ACUs have a general objective of reducing the prevalence of HIV/AIDS among the university community, reaching out to infected and affected groups both within and outside the universities, offering counselling services for those living with AIDS and their families and demystifying the disease (Wawire et al., 2006).

\section{The need for corporate governance reforms}

The challenges facing public universities in Kenya indicate the need for reforms in the management of the said institutions. This means that there is need for leaders of institutions of higher education to implement broad policy changes since change is part and parcel of organizational life. Organizations that don't adapt to change risk the hazards of stagnating or going out of business. In fact, the ability to adapt to a changing environment is a source of competitive advantage. Improved governance of public universities benefits a wide range of stakeholders that include students and employers. 
Mwiria et al. (2006) point out that governance is the most critically needed area of reform in the management of public universities in Kenya. These authors contend that poor corporate governance practices in Kenyan public universities have contributed to numerous strikes and closures over the past decade. Strikes and closures have led to prolonged time for students to graduate and disrupted academic life. Further, some prospective students and resident staff have been forced to opt for the private universities and overseas institutions. Mwiria et al. (2006) opine that some of the governance issues that need to be addressed relate to management structures, student affairs, staff and student associations, appointment of chancellors, and the role of the Commission for Higher Education (CHE).

\section{Conclusions}

This paper has reviewed the corporate governance practices adopted by public sector organizations in Kenya especially the public universities. From the literature review, the following conclusions have been arrived at.

Firstly, there is very little research done in the area of corporate governance in developing economies especially those in Africa (Okeahalam, 2004; Shleifer \& Vishny, 1997). Hynes (2010) notes that the Kenyan government is trying to improve ethics and governance in public and private enterprises in an effort to attract foreign direct investment (FDI). This implies that there is need for more research on corporate governance in the said country.

Secondly, Kenyan public universities are faced with a myriad of challenges or areas that need to be reformed. Mwiria et al. (2006) perceive governance to be the most critically needed area of reform for Kenyan public universities. Governance affects a wide range of stakeholders. Poor governance structures have been associated with disrupted academic life. Moreover, governance involves the recruitment of individuals managing institutions of higher education and determines the relevance of management structures. A policy implication is that Kenyan public universities should consider governance as a serious issue and train their council and university management board members on its application and importance.

Thirdly, the corporate governance practices used in developed countries are not directly applicable in developing economies because of political, economic, technological and cultural differences (Mensah 2002; Rabelo \& Vasconcelos, 2002). This means that there is a need to develop models of corporate governance that consider the conditions in each developing country and that are not directly borrowed from developed countries.

The issues identified in this paper can form a research topic for future researchers. The proper governance of public sector organizations in developing countries can result to value addition on the part of their numerous stakeholders.

\section{References}

Adams, M. A. (2002). The convergence of international corporate systems - where is Australia heading? (Part 1), Keeping Good Companies Journal, 54(1), 14-21.

Adams, M. A. (2002). The convergence of international corporate systems - where is Australia heading? (Part 2), Keeping Good Companies Journal, 54(2), 82-87.

Altbach, P. G. (1970). Higher Education in Developing Countries: A Select Bibliography. Harvard: Harvard University Center for International Affairs, Occasional Papers in International Affairs, no. 24.

Amutabi, M.N. (2002). Crisis and student protest in universities in Kenya: examining the role of students in national leadership and the democratization process, African Studies Review, 45 (2), 157-177. doi:10.2307/1514792, http://dx.doi.org/10.2307/1514792

ASX Corporate Governance Council, (2003). Principles of Good Corporate Governance and Best Practice Recommendations, Sydney: Australian Stock Exchange.

Audit Commission, (2009). Coroprate governance framework', Audit Commission, London, [Online] available: www.auditcommission.gov.uk/SiteCollectionDocuments/Downloads/ $\left(12^{\text {th }}\right.$ October 2010$)$.

Australian Standard, (2003). Good governance principles, AS8000-2003, Sydney: Standards Australia International.

Baird, K. (2007). Adoption of activity management practices in public sector organizations, Accounting and Finance, 47, 551-569. doi:10.1111/j.1467-629X.2007.00225.x, http://dx.doi.org/10.1111/j.1467-629X.2007.00225.x

Berle, A. \& Means, G. (1967). Private Property and the Modern Corporation, New York: Macmillan.

Birdsall, N. (1996). Public Spending on Higher Education in Developing Countries: Too Much or Too Little?

Economics of Education Review, 15(1), 407-419. doi:10.1016/S0272-7757(96)00028-3, http://dx.doi.org/10.1016/S0272-7757(96)00028-3

Blair, M.M. (1995). Ownership and Control, Washington: The Brookings Institutions.

Cadbury, A. (2000). The corporate governance agenda, Corporate Governance, 8(1), 7-15.

doi:10.1111/1467-8683.00175, http://dx.doi.org/10.1111/1467-8683.00175 
Carnoy, M. (1986). Education for Alternative Development, in G.Philip, Altbach \& P. K Gail (Eds.). New Approaches to Comparative Higher Education (pp. 73-90), Chicago: The University of Chicago Press.

Carpenter, M.A. \& Westpal, J.D. (2001). The strategic context of external network ties: Examining the impact of director appointments on board involvement in strategic decision making, Academy of Management Journal, 44 (4), 639-990. doi:10.2307/3069408, http://dx.doi.org/10.2307/3069408

Chartered Institute of Public Finance and Accountancy and the Society of Local Authority Chief Executives, (2007), Corporate governance in local government: a keystone for community governance, Chartered Institute of Public Finance and Accountancy and the Society of Local Authority Chief Executives, Online] available: http://secure.cipfa.org.uk/cgi-bin/CIPFA. storefront/EN/product/BU012 (12th October 2010).

Clarke, T. (2004). Introduction: theories of governance - reconceptualising corporate governance theory after the Enron experience, in T. Clarke (Ed.), Theories of Corporate Governance: the philosophical foundations of corporate governance, Abingdon: Routledge.

Coase, R.H. (1937). The Nature of the Firm, Economica, 4, 386-405. doi:10.1111/j.1468-0335.1937.tb00002.x, http://dx.doi.org/10.1111/j.1468-0335.1937.tb00002.x

Colley, J.L.,Doyle, J.L., Logan, G.W., \& Stettinius, W. (2004). What is Corporate Governance, Black lick:

McGraw-Hill.

Committee on the Financial Aspects of Corporate Governance, (1992), Report of the Committee on the Financial Aspects of Corporate Governance, (Sir Adrian Cadbury, chairman), London : Gee.

Currall, S.C. \& Epstein, M.J. (2003). The fragility of organizational trust: lessons from the rise and fall of Enron, Oranizational Dynamics, 32(2), 193-206. doi:10.1016/S0090-2616(03)00018-4, http://dx.doi.org/10.1016/S0090-2616(03)00018-4

Cutting, B. \& Kouzim, A. (2000). The emerging patterns of power in corporate governance - back to the future in improving corporate decision making, Journal of Managerial Psychology, 15(5), 477-507. doi:10.1108/02683940010337211, http://dx.doi.org/10.1108/02683940010337211

Davies, M. \& Schlitzer, B. (2008). The impracticability of an international "one size fits all" corporate governance code of best practice, Managerial Auditing Journal, 23(6), 532-544. doi:10.1108/02686900810882093, http://dx.doi.org/10.1108/02686900810882093

de Wit, M.,Wade, M. \& Schouten, E. (2006). Hardwiring and softwiring corporate responsibility: a vital combination, Corporate Governance, 6(4), 491-505. doi:10.1108/14720700610689595, http://dx.doi.org/10.1108/14720700610689595

Demb, A. \& Neubauer, F.F. (1992). The Corporate Board: Confronting the Paradoxes, Long Range Planning, 25(3), 9-20. doi:10.1016/0024-6301(92)90364-8, http://dx.doi.org/10.1016/0024-6301(92)90364-8

Department of the Treasury, (1997). Directors' Duties and Corporate Governance: facilitating innovation and protecting investors, Corporate Law Economic Reform Program Proposals for Reform: Paper No.3, Canberra: AGPS.

Dobson, J. (1991). Ethics of Shareholder Referendums: Corporate Democracy or Hypocrisy? Review of Business, 13(3), 22-26.

Donaldson, L. \& Davis J. (1991). Stewardship Theory or Agency Theory: CEO Governance and Shareholder Returns, Australian Journal of Management, 16(49), 50-53.

Donaldson, T. \& Preston, L.E. (1995). The stakeholder theory of the corporation: concepts, evidence and implications, Academy of Management Review, 20(1), 65-91. doi:10.2307/258887, http://dx.doi.org/10.2307/258887

Dunphy, D., Griffiths, A., \& Benn, S. (2003). Organizational Change for corporate sustainability, London: Routledge,.

Eisenhardt, K.M. (1989). Building theories from case study research, Academy of Management Review, 14(4), 532-550. doi:10.2307/258557, http://dx.doi.org/10.2307/258557

Fletcher, K. (1996). Developing appropriate organisational structures for non-profit associations, in $M$. McGregor-Lowndes, K. Fletcher, \& A.S. Sievers (Eds.), Legal Issues for Non-profit Associations, North Ryde NSW: LBC Information Services,

Francis, R.D. (2000). Ethics and Corporate Governance: an Australian handbook, Sydney: UNSW Press.

Freeman, R.E. (1984). Strategic Management: A Stakeholder Approach, Boston: Pitman.

Freeman, R.E \& McVea, J. (2001). A Stakeholder approach to strategic management, in M.A Hitt, R.E Freeman \& J.S Harrison (Eds.), Handbook of Strategic Management, (pp. 189-207), Oxford: Blackwell.

Gompers, P.A., Ishii, J. \& Metrick, A. (2003). Corporate Governance and Equity Prices, Quarterly Journal of

Economics, 118(1), 107-155. doi:10.1162/00335530360535162, http://dx.doi.org/10.1162/00335530360535162 
Gregg, S. (2001). The Art of Corporate Governance: a return to first principles, St Leonards NSW: Centre for Independent Studies.

Gregory, H.J. (2000). The Globalization of Corporate Governance, Global Counsel, October.

Guedeghe, C. M. (1997). Research on Higher Education in sub-Saharan Africa, in J. Sadlak \& P. G. Altbach (Eds.),

Higher Education Research at the Turn of the New Century: Structures, Issues, and Trends. Eds. Paris: Garland Publishing..

Hawley, J. P. \& Williams, A.T. (1996). Corporate Governance in the United States: The Rise of Fiduciary Capitalism, School of Economics and Business Administration, California: St Mary's College.

Hilmer, F.G. (1998). Strictly Boardroom: improving governance to enhance company performance, $\left(2^{\text {nd }}\right.$ ed. $)$, Melbourne: Information Australia.

Jarrar, Y. \& Schiuma, G. (2007). Measuring performance in the public sector: challenges and trends, Measuring Business Excellence, 11(4), 4-8. doi:10.1108/13683040710837883, http://dx.doi.org/10.1108/13683040710837883

Kakabadse, N.K. \& Kakabadse, A. (2003). Polylogue as a platform for governance: integrating people, the planet, profit and posterity, Corporate Governance, 3(1), 5-38. doi:10.1108/14720700310459845, http://dx.doi.org/10.1108/14720700310459845

Kaptein, M. \& Van Tulder, R. (2003). Toward effective stakeholder dialogue, Business and Society Review, 108(2), 203-24. doi:10.1111/1467-8594.00161, http://dx.doi.org/10.1111/1467-8594.00161

Kiel, G. \& Nicholson, G. (2002). Real world governance: driving business success through effective corporate governance, Mt Eliza Business Review, Winter/Spring, 1-12.

Kiel, G. \& Nicholson, G. (2003). Boards That Work, Sydney: McGraw-Hill.

Mackenzie, C. (2007). Boards, incentives and corporate social responsibility: the case for a change of emphasis, Corporate Governance: An International Review, 15(5), 935-43.

Mallin, C.A. (2004). Corporate Governance, Oxford: Oxford University Press.

Manville, B. \& Ober, J. (2003). Beyond empowerment: building a company of citizens, Harvard Business Review, 81(1), 48-53.

McNutt, P.A. (2010). Edited ethics: corporate governance and Kant's philosophy, International journal of Social Economics, 37(10), 741- 754.

Melese, F., J. Blandin, \& O'Keefe, S. (2004). A new management model for government: integrating activity based costing, the balanced scorecard and total quality management with the planning, programming and budgeting system, International Public Management Review, 5, 103-131.

Monks, R.A.G. (2002). Redesigning corporate governance structures and systems for the 21st century, paper delivered to the 5th International Conference on Corporate Governance and Direction at the Centre for Board Effectiveness, Henley Management College.

Monks, R.A.G \& Minow, N. (1996). Watching the Watchers: corporate governance for the 21st century, (rev ed.) Cambridge: Blackwell.

Muchiri, K. (2010). Kenya's varsity enrolment to shoot up in shake-up, Nairobi: Daily Nation newspaper (1/10/2010).

Mwiria, K. \& Ng'ethe, N. (2006). Public University Reform in Kenya: Mapping the Key Changes of the Last Decade, Nairobi: East Africa Educational Publishers.

Neuman, W.L. (2006). Social Research Methods: Qualitative and Quantitative Approaches, ( $6^{\text {th }}$ ed.), Boston: Allyn \& Bacon.

Ogom, R.O. (2007). Tertiary Education and Development in Sub-Saharan Africa at the Dawn of the Twenty First Century: A Lost Hope, Or Present Opportunity? National Social Science Journal, 29(1), 108-120.

Oketch, M. (2004). The emergence of private university education in Kenya: trends, prospects, and challenges, International Journal of Education Development, 24, 119-136. doi:10.1016/j.ijedudev.2003.10.005, http://dx.doi.org/10.1016/j.ijedudev.2003.10.005

Organisation for Economic Cooperation and Development, (1998), Corporate Governance: improving competitiveness and access to capital in global markets, a report to the OECD by the Business Sector Advisory Group on Corporate Governance, Paris: OECD. 
Parker, H. (1996). Re-empowering the board: an agenda for action, in R.A.G. Monks \& N. Minow (Eds.), Watching the watchers: corporate governance for the 21st century, (rev ed.), Cambridge: Blackwell.

Qudrat-I Elahi, K. (2009). UNDP on good governance, International Journal of Social Economics, 36(12), 1167-80. doi:10.1108/03068290910996981, http://dx.doi.org/10.1108/03068290910996981

Ramon, V.R. (2001). Corporate Governance as Competitive Advantage in Asia: Managing Corporate Governance in Asia, Asian Institute of Management, Philippines.

Rothman, J. \& Friedman, V.J. (2001), Identity, conflict, and organizational learning, in M.Dierkes, A.B. Antal, J.Child \& I. Nonaka (Eds.), Handbook of Organizational Learning and Knowledge, (pp. 582-97), New York: Oxford University Press.

Ruin, J.E. (2001). Essentials of Corporate Management, Kuala Lumpur: MICG.

Rwegasira, K. (2000). Corporate governance in emerging capital markets: whither Africa? Corporate Governance: An International Review, 8(3), 258-67. doi:10.1111/1467-8683.00203, http://dx.doi.org/10.1111/1467-8683.00203

Scott, W. R. (2003). Organizations: Rational, Natural, and Open systems, (5 ${ }^{\text {th }}$ ed.), Englewood Cliffs: Prentice-Hall.

Shleifer, A. \& Vishny, R.W. (1997). A survey of corporate governance, The Journal of Finance, 52(2), 737-783. doi:10.2307/2329497, http://dx.doi.org/10.2307/2329497

Solomon, J. \& Solomon, A. (2004). Corporate Governance and Accountability, Chichester :Wiley.

Starik, M. \& Rands, G. (1995). Weaving an integrated web: multilevel and multisystem perspectives in ecological sustainability organisations, Academy of Management Review, 20(4), 908-35. doi:10.2307/258960, http://dx.doi.org/10.2307/258960

Tadjudin, M.K. (2003), Mutual recognition of Qualifications in the Context of Indonesia. Paper Presented in International Network for Quality Assurance Agencies in Higher Education (INQAAHE), Asia Pacific Sub-Network Forum, Hong Kong, China, [Online] available: http://www.hkcaa.edu.hk (12 ${ }^{\text {th }}$ October 2010).

Turnbull, S. (1997). Corporate governance: Its scope, concerns \& theories, Corporate Governance: An International Review, 5(4), 180-205.

Turnbull, S. (2002), A New Way to Govern Organizations and Society after Enron, London: New Economics Foundation.

Ulrich, P. (2008). Integrative Economic Ethics: Foundations of a Civilized Market Economy, Cambridge: Cambridge University Press. doi:10.1017/CBO9780511488658, http://dx.doi.org/10.1017/CBO9780511488658

United Nations (1999). Editorial: corporate governance - the global state of the art, Corporate Governance: An International Review, 7(2), 117-122.

Van den Bor, W. \& James C.M. (1991). Higher Education in the Third World: Status Symbol or Instrument for Development? Higher Education, 22(1), 1-15. doi:10.1007/BF02351196, http://dx.doi.org/10.1007/BF02351196

Varghese, N. V. (2006), Executive Summary in UNESCO's "Growth and expansion of private higher education in Africa." [Online] available: http://www.unesco.org/iiep (18th October 2010).

Vinten, G. (2001). Corporate governance and the sons of Cadbury, Corporate Governance, 1(4), 4-8. doi:10.1108/14720700110404289, http://dx.doi.org/10.1108/14720700110404289

Wallace, P. \& Zinkin, J. (2005). Mastering Business in Asia Corporate Governance, Singapore: John Wiley \& Sons.

Watkins, S. (2003). Former Enron vice president Sherron Watkins on the Enron collapse, Academy of Management Executive, 17(4), 119-25.

Wesonga, D., Ngome, C., Ouma-Odero, D. \& Wawire, D. (2006). Private Provision of Higher Education in Kenya: Trends \& Issues in Four Universities, Nairobi: East Africa Educational Publishers.

Wheelen \& Hunger, (2002), Corporate governance and social responsibility' [Online] available: http://vig.prenhall.com/catalog/uploads/Wheelan-Hunger Ch2.ppt , (16 June 2010).

White, A.L. (2009), Democratizing the corporation, in H.Spitzeck, M.Pirson, W. Amann,. S.Khan, \& E. Von Kimakowitz, (Eds.), Humanism in Business, (pp. 229-47), Cambridge: Cambridge University Press.

Zandstra, G. (2002). Enron, board governance and moral failings, Corporate Governance, 2(2), 16. doi:10.1108/14720700210430333, http://dx.doi.org/10.1108/14720700210430333 
Table 1. The ASX corporate governance principles

1. Lay solid foundations for management oversight
2. Structure a board to add value
3. Promote ethical and responsible decision-making
4. Safeguard integrity in financial reporting
5. Make timely and balanced disclosure
6. Respect the rights of shareholders
7. Recognise and manage risks
8. Encourage enhanced performance
9. Remunerate fairly and responsibly
10. Recognise the legitimate interests of stakeholders

Source: adapted from the ASX Corporate Governance Council (2003).

Table 2. Key elements of a good corporate governance environment

\begin{tabular}{|l|l|}
\hline \multicolumn{1}{|c|}{ Principle } & \multicolumn{1}{|c|}{ Source } \\
\hline Lay a solid foundation for management & $\begin{array}{l}\text { The Business Roundtable (2002) } \\
\text { ASX Corporate Governance Council (2003) }\end{array}$ \\
\hline Establish a board that adds value & $\begin{array}{l}\text { ASX Corporate Governance Council (2003) } \\
\text { Cadbury Report (1992) UK }\end{array}$ \\
\hline Equitable treatment of shareholders & $\begin{array}{l}\text { OECD (1999) } \\
\text { The Business Roundtable (2002) } \\
\text { ASX Corporate Governance Council (2003) }\end{array}$ \\
\hline $\begin{array}{l}\text { Accurate and timely disclosure of financial, } \\
\text { performance, ownership, and governance matters }\end{array}$ & $\begin{array}{l}\text { ASX Corporate Governance Council (2003) } \\
\text { The Business Roundtable (2002) } \\
\text { OECD (1999) }\end{array}$ \\
\hline $\begin{array}{l}\text { Effective monitoring of management and the } \\
\text { accountability of the board }\end{array}$ & $\begin{array}{l}\text { OECD (1999) } \\
\text { ASX Corporate Governance Council (2003) } \\
\text { Sarbanes-Oxley Act 2002 ('SOX'). } \\
\text { The Business Roundtable (2002). }\end{array}$ \\
\hline $\begin{array}{l}\text { Operating ethically and responsible decision making } \\
\text { ASX Corporate Governance Council (2003) } \\
\text { The Business Roundtable (2002) }\end{array}$ \\
\hline $\begin{array}{l}\text { Fairness in dealing with employees } \\
\text { ASX Corporate Governance Council (2003) } \\
\text { OECD (1999) }\end{array}$ \\
\hline $\begin{array}{l}\text { The Business Roundtable (2002) } \\
\text { ASX Corporate Governance Council (2003) } \\
\text { OECD (1999) } \\
\text { The Business Roundtable (2002), }\end{array}$ \\
\hline
\end{tabular}

Source: developed for this paper. 
Table 3. Private universities in Kenya

\begin{tabular}{|c|c|c|}
\hline Category & Names of private university & $\begin{array}{c}\text { Brief description of the } \\
\text { university }\end{array}$ \\
\hline Chartered universities & $\begin{array}{ll}\text { - } & \text { African Nazarene University } \\
\text { - } & \text { Catholic University of Eastern } \\
\text { - } & \text { Daystar university } \\
\text { - } & \text { Kabarak University } \\
\text { - } & \text { Strathmore University } \\
\text { - } & \text { University of Eastern Africa, } \\
\text { - } & \text { St. Paraton } \\
\text { - } & \text { Kenya Methodist University } \\
\text { - } & \text { The Pan-Africa Christian } \\
\text { - } & \text { Sniversity } \\
\text { - } & \text { United States International } \\
& \text { University (USIU) }\end{array}$ & $\begin{array}{l}\text { They are fully chartered and } \\
\text { offer their own degrees }\end{array}$ \\
\hline $\begin{array}{l}\text { Universities operating under } \\
\text { Letters of Interim Authority }\end{array}$ & $\begin{array}{ll}\text { - } & \text { Aga Khan University } \\
\text { - } & \text { Great Lakes University of } \\
\text { - } & \text { Kisumu } \\
\text { Kiriri Women's University of } \\
\text { - } \\
\text { Theience and Technology } \\
\text { - } \\
\text { East Africa } \\
\text { - } \\
\text { - } \\
\text { - } \\
\text { KCA Kentist Univenya University } \\
\text { Gretsa University }\end{array}$ & $\begin{array}{l}\text { They have been given a letter } \\
\text { of interim authority to run } \\
\text { degree programmes as they } \\
\text { await registration and } \\
\text { charters. }\end{array}$ \\
\hline $\begin{array}{l}\text { Universities operating with } \\
\text { Certificates of Registration }\end{array}$ & $\begin{array}{l}\text { - The Nairobi International } \\
\text { School of Theology } \\
\text { - The East Africa School of } \\
\text { Theology } \\
\text { - The Nairobi Evangelical } \\
\text { Graduate School of Theology } \\
\text { - Kenya Highlands Bible College }\end{array}$ & $\begin{array}{l}\text { These private universities } \\
\text { operate under certificates of } \\
\text { registration granted by the } \\
\text { Commission for Higher } \\
\text { Education (CHE). }\end{array}$ \\
\hline
\end{tabular}

Source: developed for this article 